SCJR 14, no. 1 (2019): 1-3

\title{
Malka Simkovich The Making of Jewish Universalism: From Exile to Alexandria
}

(London: Lexington Books, 2017), hardcover, xxx + 185 pp.

\author{
MATTHEW GOLDSTONE \\ mgoldstone@ajrsem.org \\ Academy for Jewish Religion, Yonkers, NY 10701
}

Malka Simkovich's The Making of Jewish Universalism explores the development of universalistic themes in Jewish literature from exilic works preserved in the Hebrew Bible through texts dating to around the turn of the millennium and likely authored in an Alexandrian milieu. She breaks with previous scholarship which either highlighted Jewish particularism with respect to Christian universalism or identified significant universalistic trends already in biblical and postbiblical Jewish literature. By contrast, she argues that employing a more refined spectrum of universalistic paradigms enables us to see critical nuances between late-biblical, post-biblical, and late-Second Temple sources connected to the Alexandrian Jewish community.

In her introduction, Simkovich reviews the relevant scholarship, outlines the trajectory of the book, and proffers a definition for universalism. Criticizing previous studies for lacking "a single, widely accepted definition of universalism" or for not clarifying how to define universalism, Simkovich says universalism means that non-Israelites / non-Jews have access to a relationship with the God of Israel "without demanding that they convert or participate in the Israelite community as a Jew" (pp. xviii-xix). Simkovich makes the case for why universalism should be opposed to conversion (i.e., joining the people of Israel), but a stronger argument for the strengths of her particular definition would have bolstered her thesis.

Simkovich distinguishes between two types of universalism: "Universalized Worship," in which everyone worships the Israelite God but "distinguishing aspects of Judaism are preserved, and ethnic boundaries between the nations remain intact," and "Ethical Universalism," in which "distinctive aspects of Judaism are dissolved, and the religious and ethnic boundaries between the nations fall to the wayside" (p. xxii). The bulk of the book is then divided into four parts; the first three each contain two chapters and the last part contains only one. In all but this 
last part, she moves chronologically from biblical prophetic literature to texts from the Greco-Roman period ( $334 \mathrm{BCE}-118 \mathrm{BCE}$ ) to works of the first century BCE. Her fourth part includes a summary of the argument. Overall, the book presents an interesting thesis but has a number of issues that partially obscure the force of the argument.

Part one of the book revolves around four different models of relationships between Israelites and non-Israelites in biblical prophetic texts: 1) Subjugation Israel dominates the other nations; 2) Standard-Bearing - The nations remain distinct but they acknowledge the Israelite God; 3) Naturalized Nations - Foreign nations are absorbed into the Israelite community; and 4) Universalized Worship - The nations worship the Israelite God but do not lose their distinct identity. Only in this last category does Simkovich see a strong move towards actual universalism. However, it is not entirely clear why the Standard-Bearing model does not also reflect a type of universalism. Similarly, the nuanced distinction between this model and the Universalized Worship model is difficult to grasp. After this introduction to these four models, in chapter one Simkovich explores the first three in selected texts: The Subjugation model in Obadiah and Amos 9:7-15, the Standard-Bearing model as exemplified in Isaiah 2:2-4 and 40-55, and the Naturalization model in Zechariah 2:10-17. She then shifts to the Universalized Worship model as manifest in Isaiah 56, Daniel 4, and Zechariah 14. Here Simkovich highlights a few key points, such as that Isaiah removes the particularist nature of Sabbath observance by encouraging foreigners to observe the day without an expectation of assimilation and that Daniel 4 and some psalms envision a type of universalism not just in the remote future, but also in "the author's present day" (p. 36).

Part two contains two chapters, a short chapter on the War Scroll, 4QBerakhot, and Greek Esther, and a comparatively lengthy chapter on the Universalized Worship model in other Second Temple period works. This latter chapter presents some important claims but has a few issues that complicate the picture. For example, Simkovich compares the two main recensions of the Book of Tobit, suggesting that the first does not envision conversion to Judaism while the second does. However, the key lines in the translations of these versions she uses are almost identical - "Then the nations in the entire world will all be converted [epistrépsousin]" - making it difficult to see the difference (pp. 70-71). On a related note, when discussing a passage from Joseph and Aseneth, Simkovich asserts that "there is no explicit mention of conversion in this scene," though there seem to be many hints in this direction: Aseneth's name is changed, it is asserted that many nations will take refuge in her with God, and she will shelter people who trust in God (p. 73). Additionally, when examining material from Philo, Simkovich claims that Philo's eschatological vision in Vit. Mos. 2.43-44 both requires and does not require conversion (pp. 78; $90 \mathrm{fn} 57$ and fn62). She concludes Part two with the observation that "some Jewish writers were adapting Greek literary concepts of homónoia to their Jewish eschatologies and worldviews" and the summary point that unlike biblical literature, which imagined universalist worship in the distant future, post-biblical literature saw this in 
the immediate present (pp. 82-83; however, see her discussion of Daniel and Psalms noted above).

Part three of the book focuses on the emergence of Ethical Universalism. After a short fifth chapter on Philo's "Radical Allegorizers," Simkovich in chapter six offers a key part of her argument. She examines The Sentences of PseudoPhocylides and the Third Sibylline Oracle in order to demonstrate that both contain elements that express Ethical Universalist thought. This chapter presents important claims but has a few puzzling features. According to Simkovich, the Third Sibylline Oracle ignores the core signifiers of Jewish identity (Sabbath, circumcision, and dietary laws) but does refer to the Exodus from Egypt and the revelation at Sinai, topics that she otherwise claims are missing or downplayed in Ethical Universalist sources (pp. xxiv, 118). Simkovich also suggests that the use of the term strépsas ("turn") in the Oracle, rather than metánoia ("conversion"), implies that conversion is not required (p. 121). However, the cited translation employs the English word "converted," and Simkovich does not mention whether the term metánoia is used with any regularity in the non-universalistic texts. Lastly, Simkovich hypothesizes a connection between ethical universalistic themes that "lie at the foreground of Stoic thought" and the Jewish works she analyzes, but her claim that "in all likelihood, the currents of influence moved in both directions" is not sufficiently supported (p. 122). Despite these subtle issues, in chapter six she makes the significant argument that universalistic elements in Second Temple Jewish sources appear primarily in those works associated with Jewish writers in Alexandria.

Part four of the book summarizes Simkovich's conclusions and spells out the implications of her claims. Overall, The Making of Jewish Universalism is an important work for those interested in the development of Second Temple-period Jewish literature and especially in those works composed in Alexandria. 